\title{
A Minimalist Strategy Towards Temporarily Defining Protection for COVID-19
}

\author{
Nevio Cimolai ${ }^{1,2}$ (1) \\ Accepted: 17 September 2020 / Published online: 19 September 2020 \\ (C) Springer Nature Switzerland AG 2020
}

\begin{abstract}
Until either efficacious therapy or vaccination for COVID-19 is achieved, there will be a need to regain world economic stability while yet controlling the pandemic with current approaches. For those infected thus far, there is a prevailing perspective that devising recognition for protective immunity will progressively allow segments of society to return to some functionality more than is existing. At this time, the best correlates with protection from natural coronavirus infections are systemic neutralizing antibody and mucosal IgA. Serum neutralizing antibody more easily fulfills the latter requisite, but current live virus methods for neutralization prevent large-scale application. It is conceivable that the exposure of previously infected individuals can allow for the definition of protective thresholds of neutralizing antibody. Thereafter, many other antibody assays will be able to screen for surrogate protection after correlations with protective neutralizing antibody are made. Specificity of common antibody tests would benefit from confirmatory blocking systems or confirmatory immunoblotting fingerprints with well-defined antigen(s). The opportunity for the scientific community to make these assessments is evident in the current context of the COVID-19 epidemic given the large numbers of infected individuals worldwide. Such information will also be vital to guide vaccine development and/or immunotherapy.
\end{abstract}

Keywords COVID-19 $\cdot$ Coronavirus $\cdot$ Protection $\cdot$ Seroepidemiology $\cdot$ Transmission

\section{Introduction}

The clinical burden of COVID-19 in the current pandemic is undoubtedly considerable, but the socioeconomic burden must equally weigh in determining how the world will move forward until either an effective chemotherapy and/or vaccine is devised [1]. Pending that such success in treatment and/or prevention are achieved, the continuous or relapsing lockdown of societies and hence economies has the potential to cause more damage than may be initially apparent [2]. Indeed, it could be prognosticated that the relative economic standstill may cause more damage to humanity than the disease itself. Many countries have attempted to partially restore

This article is part of the Topical Collection on Covid-19

Nevio Cimolai

ncimolai@mail.ubc.ca

1 Faculty of Medicine, The University of British Columbia, Vancouver, Canada

2 Children's and Women's Health Centre of British Columbia, 4480 Oak Street, Vancouver BC V6H3V4, Canada pre-pandemic functions only to experience yet second waves of increasing infections during July and August, 2020. To some, the answer may be to tolerate the expectations of herd immunity with lesser in the way of resistance to infection spread $[3,4]$. To others at the other end of the spectrum, a more cautious approach has been to create the best environment for disease prevention while patching holes for or propping up failures in the economy as they appear [3]. Somewhere in the midst of this maelstrom, there will need to be practical strategies for achieving success with both the pandemic and the economies simultaneously. Contexts of disease and economy will no doubt vary along a spectrum and may require somewhat different approaches in their detail.

In this review, a minimalist strategy is proposed to in part provide some solutions towards regaining economic focus while preventing disease. These steps are a modest beginning from the perspective of devising recognition for protective immunity that will progressively allow segments of society to proceed with their lives as they once were or nearly so. Such a strategy will thereafter be enhanced as treatment or vaccine developments arise. 


\section{Provisional Acceptance of What Constitutes Immunity}

Studies with passive immunity are highly suggestive that antibody has a significant role in protection of coronavirus infection [5-12]. The latter includes passive administration of anti-SARS-CoV-2 human monoclonal antibody in animal systems [13]. These findings are critical to our theme since direct antibody in some way may be used as the correlate with neutralization if not directly then by association. Therefore, the prospects of finding a serological assay based on antibody detection that defines in some way neutralization and then after disease prevention are considerable.

Infection with coronaviruses generally protects against reinfection [12, 14-22]. Analogous to the role of passive immunity, pre-existing immunity can potentially be defined with the right measures.

Both parenteral neutralizing antibody and secretory IgA $(\operatorname{sig} \mathrm{A})$ are associated with protection in model systems [14, 15, 23-27]. sIgA has logistical problems with collection and analysis, although technological advances are quite likely capable of overcoming the latter. Therefore and in the interim, serum neutralizing antibody measurements will generally be applied as the standard, and other correlates of the latter could be put into common use.

For MERS, mild infection was associated with decreased antibody levels [28-30]. Severe infections are associated with long-lived neutralizing antibody. Increased neutralizing antibody is associated with decreased viral shedding, but there have not been enough natural infections to allow for study and analysis of natural protection as would be desirable. Likewise for SARS, field studies for the practical protective effects of neutralizing antibody could not be studied due to the short-lived spread of the virus.

In studies for SARS-CoV-2, of over 700 control sera from uninfected patients, no neutralizing antibodies were found [31]. Severe disease was associated with earlier generation of anti-SARS-CoV-2 antibody, and peak neutralizing antibody was measured at approximately $2 \frac{1}{2}$ weeks. Stereotypic antibody responses to SARS-CoV-2 led to hypotheses that there should be cross-reactivity with SARS-CoV in the constant RBD [32]. In both humans and animals, such cross-reactivity was suspected to be due to non-neutralizing anti-S antibody again likely relating to a conserved region [33]. Crossneutralization was however uncommon, but conceivably there could be other reasons for any such non-specificity [34-36]. Among humans, S-specific antibody dominates and may correlate better with neutralization [34, 35, 37]. Furthermore, the correlation between antibodies for different antigens (e.g., S and $\mathrm{N}$ proteins) may not be as initially conceived $[35,38]$. Human monoclonal antibodies that neutralize virus or pseudovirus especially recognized the RBD [39]. Collaborative groups have found a strong association between neutralizing antibodies and $\operatorname{IgG}$ antibodies to the RBD [36, 40]. Others have found strong correlations between neutralizing antibodies and EIA-detected antibodies to various SARS-CoV-2 antigens [41, 42].Some have found diversity in immune responses contingent on the nature of presenting disease $[38,43]$. The latter would be consistent with the variable antibody responses now determined for the spectrum of pediatric disease [44]. For EIA-based antibody studies otherwise, we have learned so far that the type and severity of disease and age may have bearing on the quality and quantity of antibody responses [34, 45-48]. Gender may also possibly affect antibody responses or other relevant immune responses [34, 49].

Does neutralization antibody ensure protection? At this time, we can reasonably conclude that the existence of neutralizing antibody and its quantitation associate with protection against coronavirus infections. What we cannot do, however, is guarantee that the presence of all such neutralizing antibody, as measured by conventional live virus neutralization methods in vitro, will ensure protection. That is, laboratory methods measure neutralization as so defined but not protection directly. Therefore, it can be held that not all neutralization methods duly measure the same effect that leads to that neutralization outcome [50]. In essence, what creates an in vitro neutralization may or may not truly block viral entry, prevent intracellular events, or ameliorate disease. One potential and theoretical approach to vetting sera that have a higher likelihood of indication for protection is to choose those with higher neutralizing titres.

There are several limitations with the application of neutralization as a surrogate for protection [25, 51]. Infections with coronaviruses do not always lead to a major increase in such antibody. Previously acquired antibody is not always protective for subsequent infection, but low levels of antibody better correlate with susceptibility. Resistance is best to the homologous coronavirus, but susceptibility can be had to heterologous strains. There is also the prospect that subsequent changes in viral genome may be accompanied by changes in epitopes that afford neutralization with an accompanying change in neutralization capacity of post-infection or post-vaccination sera [52]. The latter could be the prelude to neutralization escape mutants should they occur [53]. The latter may also be the prelude to emerging reports of possible SARS-CoV-2 repeat infections [54].

The traditional approach to determining antibody responses is likely to dominate the search for protective immunity, but due consideration and open-mindedness should be maintained for measuring $\mathrm{T}$ cell post-infection immunity and its correlates [55-58]. 


\section{The Need for Blocking Tests or Fingerprints in Confirmatory COVID-19 Seroepidemiology}

With the availability of viral antigen, most scientists in the know-how would be able to fashion a test for antibody determination in short order and most would likely choose an enzyme immunoassay (EIA) (or nearly equivalent non-enzymebased assay) for its potential of automation and widespread use. The latter is especially likely in the current context where a majority of serodiagnostic tests are of that methodology. The expeditious derivation of an EIA or equivalent is a common goal when serodiagnosis is deemed to be of potential value. Whereas the creation of an EIA is seemingly a relatively easy task, the application of any such is where the test of the matter lies. Historically, whether for antibody or antigen detection, EIA approaches had a number of pitfalls that were repetitively realized for nearly every such system that was subsequently developed $[59,60]$. As would naturally be desirable, an assay with very high sensitivity at the appropriate timing is one evident target. Furthermore, an assay with a highly specific result is another evident target. The reality of serodiagnostic systems, however, is that there is generally a gray or indeterminate zone where sensitivity and specificity collide [60]. There is an intersection of true positive results and false positive results more or less in almost every system with few exceptions. For whatever maneuver is conceived to diminish that overlap, EIA or an equivalent for antibody detection can be modulated to enhance predictive values in one direction or another, but commonly realizing that there will be a trade-off.

The application of a serodiagnostic assay for antibody postinfection or vaccine is furthermore complicated in its evaluation. Typically, a standard set of known or presumed "negative" sera are tested as is a standard set of known or presumed "positive" sera. Many such analyses, however, do not thereafter assess the assay in the context of the working world prospectively. The jeopardy here is that the prevalence of true disease in the population of patients from whom sera are acquired can vary considerably. There is an inherent bias in such assessments to ensure that the tested serum pool has a considerable number of true positive samples. Biases in this regard can be greater than those engendered by convenience sampling [61, 62]. Given the functionality of these assays, the predictive values of positive or negative tests vary considerably depending on the prevalence of the infection in the population so studied [63]. For example, even for a given high sensitivity and specificity, a reduction in prevalence from 30 to $3 \%$ can lead to a situation where the false positive assays nearly equal the number of true positive assays. The latter scenario can occur when assessments are performed on preselected sera rather than on sera from patients prospectively collected in a larger population. Therefore, unless there is considerably widespread infection leading to a proportionately high seroprevalence, serodiagnostic tests will likely suffer with their predictive values. How would this dilemma then be potentially overcome?

One such approach to improving specificity would be to conduct blocking assays (direct or competitive) for positive sera in order to reduce the number of false positive tests [64]. This is a time-honored approach that is often forgotten when new serodiagnostic assays are initially created. The approach was also germane to some antigen detection EIA versions. Effectively, the specificity is enhanced when it can be shown that the antigen of choice significantly reduces the assay quantitation after absorption. The implementation of a blocking step can be entered into an automated procedure in tandem from the start or may be performed as a confirmatory test. The latter is especially suited to a scenario where the proportion of positive tests is low. The simplicity of a blocking test mandates only a brief turnaround time if it is performed in an algorithmic second step. There may be various approaches to the definition of antigen used in the blocking test, but it would be best in the inaugural stages to choose antigen(s) that are deemed inherent to the neutralization effects seen in postinfectious sera. Although it could prove that one antigen, e.g., RBD or spike protein sequence otherwise, may alone suffice, pilot studies would be better to work backwards after establishing the antigen-neutralization correlates as described above. Purity of the blocking antigen is essential to avoid non-specific competition of non-viral elements if virus is acquired from tissue cultures. Another approach to a blocking assay would be the competition between antibody in the human serum specimen and a known monoclonal antibody with affinity to SARS-CoV-2. Choice of a specific monoclonal antibody, or several for this purpose, requires specific characterization. There are many commercial assays for SARS$\mathrm{CoV}-2$ antibody that have emerged, but for a survey sample of several so assessed thus far, none has blocking assays as potentially part of the procedure [65-71]. Developmental assays also commonly do not include blocking assays [72-74]. IgM assays are particularly an issue with non-specificity since apparent IgM rises may relate in part to solid phase (e.g., polystyrene) absorption or non-specific IgM antibody (e.g., rheumatoid factor). Of note, early reports have now emerged of blocking assay variations for systems relating to either MERS-CoV or SARS-CoV-2 [75-77].

As suggested above, antigen detection can also suffer from non-specificity, and this dilemma has now been found in some systems [78-80]. Again, a blocking assay in any such configuration for antigen detection has potential to resolve this critical issue especially when raising the threshold for the enhancement of sensitivity is being considered.

A second approach, alone or alongside an EIA-blocking assay, could be immunoblotting. Again, it could prove that one antigen substrate may suffice, but it would be prudent to work backwards after establishing the antigen-neutralization correlates. As experienced pointedly with Lyme disease or 
HIV infections, the immunoblot response can be considerably variable, but a confirmatory fingerprint or several fingerprints can be defined as minimal diagnostic thresholds. A higher threshold stringency can enhance serodiagnostic specificity. Guan and others provided some key insights in this regard with SARS-CoV immunoblotting, and it is only highly probable that similar findings will be had with SARS-CoV-2 [81]. Not all antigens identified in immunoblotting may have functions in neutralization, and likewise, there may be more antigens that are capable of inducing neutralization than are identified by resolving antigens in denaturing electrophoresis procedures [50]. Given advances as detailed by Olvera et al. and several others, the fingerprint patterns could also conceivably be assessed with peptide sets rather than larger antigens which may bear non-specific epitopes [50, 81, 82]. The protein micro-array concept bears relevance to the ingenuity of how a complex recognition pattern could occur and be thereafter automated $[82,83]$. Furthermore, we should not restrict ourselves to common antigens that are currently thought relevant since novel key antigens may yet arise [55].

If serological methods of choice later prove to be a surrogate for infectious virus neutralization, e.g., viral pseudoparticles, blocking test components can also be built into those processes [84-88]. The latter approaches too are capable of automation design or large batch processing. If conventional neutralization assays yield titres in lower dilution than pseudotype virus neutralization assays (e.g., S protein-bearing pseudoviruses with murine leukemia virus), the latter may set higher thresholds as the correlation dictates [89].

\section{Setting Safe Thresholds for Protective Immunity}

If neutralizing antibody correlates with protection, is there a threshold at which the prediction can be confident? Whereas there are no guarantees, if the presence of neutralizing antibody correlates with protection, it can be reasonably hypothesized that more protection correlates with higher titres. Such a hypothesis is easily testable in the current pandemic given preliminary consensus for the type of neutralization assay to be used. It is proposed that the 1:32-1:40 standard of conventional neutralizing antibody be used as the minimal threshold in inaugural studies. The threshold could be raised or lowered depending on the outcome of field assessments. Prospective follow-up of study subjects with the established minimum neutralizing antibody and its potential change in titre and/or protection would be determinable over time.

There is then a role for other measures of antibody thereafter. As the initial neutralizing antibody threshold for protection is established, correlates with other tests as surrogates can then begin. In the latter, it would also be best to choose higher thresholds of positivity rather than any positive test per se. Such thresholds could thereafter vary pending correlations that become apparent. Such an approach provides an abundance of precaution rather than the converse.

\section{The Acid Tests of Assessing a Strategy}

The test of a minimalist strategy and thereafter its refinement is currently feasible in the milieu of the current pandemic. Given the magnitude of infected individuals throughout the world, the numbers required to test for protection could be easily acquired from a multi-centered approach with highly endemic foci or with even a regional study again in a highly endemic area. There will be concern in allowing previously infected, neutralizing antibody-positive individuals to be naturally exposed once again in the community, but such an approach has little difference to the broad testing of candidate vaccines. Indeed, the answers may come sooner than the answers of whether vaccine candidates will succeed.

Infection exposures in the community for those previously infected with or without such antibody markers will also slowly answer other questions relating to those with low level neutralizing antibody (e.g., below threshold), those that do not have any measurable antibody, anamnestic responses, and susceptibility to changing virus.

Furthermore, the minimalist strategy will potentially set the goal posts for vaccine evaluations.

\section{Translational Case Studies and their Implications}

Reports of repeat SARS-CoV-2 infections have already begun to emerge as the pandemic continues [54, 90-92]. Undoubtedly, much more similar information will be collated anecdotally or in larger series and observations. An analysis of these is relevant in considering any minimalist strategy.

Gousseff et al. present a case series of healthcare workers and community patients who appeared to have a relapsing pattern of COVID-19 [90]. The establishment of re-infection within such a short period of time is tenuous at best. Early and later positive diagnostic samples could be assessed with viral sequencing. Serological profiling with both $\operatorname{IgG}$ and $\operatorname{IgM}$ and correlation with viral neutralization are additional tools of interest. The persistence of viral genome after acute infection, and as determined with genetic amplification technology, is well-known and can be measured in weeks. Accordingly, comparison of diagnostic cycle thresholds can be of value as was done. Co-determination of other pathogens, especially viral for co-infection, is essential. That some patients may clinically relapse with a complicating respiratory illness after an initial non-complicated illness is in keeping with many 
other respiratory infections. Viral culture to confirm live virus provides an additional step in confirmation but evidently is difficult to achieve without support from reference level 3 laboratories. As the authors suggest, are these examples simply ones of persistence or re-infection?

Bentivegna et al. describe a 69 -year female with possible re-infection in which repeat RT-PCR positive samples of the respiratory tract were obtained in the context of four negative samples in between over a 6-7-week period [91]. Immunoglobulin $\mathrm{G}$ serology was reactive on each occasion. IgM serology was reactive only late in the second putative infection. Blocking assays for the second serology could have potential use if devised. Neutralization tests would have been of value to correlate with putative protection. An established fingerprint of immunoblotting if devised could be sought for in both early and later blood samples to further characterize the quality of immune reactivity. This case report emphasizes the role for a better understanding of applicable diagnostic and confirmatory serology.

Tomassini et al. highlight a case series of six patients who were possibly re-infected [92]. IgM serology, blocking for IgG serology, neutralization correlates, and comparison of diagnostic $\mathrm{Ct}$ values all have their potential merit.

To and colleagues describe a repeat infection in a 33-year male in which two distinct isolates were believed to have been identified by whole-genome sequencing [54]. The episodes occurred some 5 months apart. Measurable IgG was not detected within 10 days of the first episode. IgM diagnostics, blocking for IgG serology, and neutralization correlates all have their potential merit. The authors initiate relevant dialog about the relevance of genetic drift and possible re-infection.

Van Elslande et al. provide some evidence for a repeat infection after a 3-month interval [93]. A comparison of diagnostic samples suggested repeat infection with phylogenetically distinct strain detections. Diagnostic serology with blocking studies, neutralization correlates, and comparison of diagnostic $\mathrm{Ct}$ value all have their potential merit. These authors repeat the theme on genetic drift and its implications.

In any of the aforementioned, sample collection and recollection validation shortly after the initial diagnostic specimen test positive can also contribute to overall accuracy of determining re-infections.

\section{Interim Fidelity to Practical Preventions}

While such an approach to defining protective immunity in the interim reaches our goals if that is possible, the otherwise sensible approaches to disease prevention should continue to be enforced. Given the current evidence on person-person direct transmission, person-person aerosol transmission, and environment-person indirect transmission, adherence to the basic principles of abrogating infection spread should be maintained as is practical. Facets of physical distancing, appropriate decontamination and disinfection, and contextappropriate use of masking all have their roles in minimizing risk. It will be the study populations where some of these preventions may be less stringent in order to test the hypotheses of natural protection after infection or vaccine prevention. Nevertheless, if we do define a highly probable and preventative serodiagnostic correlation, the modes of prevention may eventually be seen in alternative fashion or stringency. The overall approach to disease control will be fluid and will adapt as the potential arises.

Acknowledgments This review is dedicated to those healthcare workers and researchers who have had the commitment to protect the populace and energetically pursue the science.

\section{Compliance with Ethical Standards}

Conflict of Interest The author declares that he has no conflict of interest.

\section{References}

1. The World Bank. The global economic outlook during the COVID19 pandemic: a changed world. 2020. https://www.worldbank.org/ en/news/feature/2020/06/08/the-global-economic-outlook-duringthe-covid-19-pandemic-a-changed-world

2. Boretti A. After less than 2 months, the simulations that drove the world to strict lockdown appear to be wrong, the same of the policies they generated. Health Serv Res Manag Epidemiol. 2020;7: 2333392820932324. https://doi.org/10.1177/2333392820932324.

3. Jung F, Krieger V, Hufert FT, Küpper J-H. Herd immunity or suppression strategy to combat COVID-19. Clin Hemorheol Microcirc. 2020;75(1):13-7.

4. Irwin RE. Misinformation and de-contextualization: international media reporting on Sweden and COVID-19. Glob Health. 2020;16(1):62.

5. Subbarao K, McAuliffe J, Vogel L, Fahle G, Fischer S, Tatti K, et al. Prior infection and passive transfer of neutralizing antibody prevent replication of severe acute respiratory syndrome coronavirus in the respiratory tract of mice. J Virol. 2004;78(7):3572-7.

6. Roberts A, Thomas WD, Guarner J, Lamirande EW, Babcock GJ, Greenough TC, et al. Therapy with a severe acute respiratory syndrome-associated coronavirus-neutralizing human monoclonal antibody reduces disease severity and viral burden in golden Syrian hamsters. J Infect Dis. 2006;193(5):685-92.

7. Zhao J, Wang W, Wang W, Zhao Z, Zhang Y, Lv P, et al. Comparison of immunoglobulin $\mathrm{G}$ responses to the spike and nucleocapsid proteins of severe acute respiratory syndrome (SARS) coronavirus in patients with SARS. Clin Vaccine Immunol. 2007;14(7):839-46.

8. Zost SJ, Gilchuk P, Case JB, Binshtein E, Chen RE, Nkolola JP, et al. Potently neutralizing and protective human antibodies against SARS-CoV-2. Nature. 2020;584:443-9. https://doi.org/10.1038/ s41586-020-2548-6.

9. Cao Y, Su B, Guo X, Sun W, Deng Y, Bao L, et al. Potent neutralizing antibodies against SARS-CoV-2 identified by highthroughput single-cell sequencing of convalescent patients' B cells. Cell. 2020;182(1):73-84.e16. 
10. Abolghasemi H, Eshghi P, Cheraghali AM, Imani Fooladi AA, Bolouki Moghaddam F, Imanizadeh S, et al. Shahverdi S Clinical efficacy and convalescent plasma for treatment of COVID-19 infections: results of a multicenter clinical study. Transfus Apher Sci 2020. 102875. https://doi.org/10.1016/j.transci.2020.102875.

11. Case JB, Rothlauf PW, Chen RE, Kafai NM, Fox JM, Shrihari S, et al. Replication-competent vesicular stomatitis virus vaccine vector protects against SARS-CoV-2-mediated pathogenesis. bioRxiv. 2020. 2020.07.09.196386. https://doi.org/10.1101/2020.07.09. 196386

12. Imai M, Iwatsuki-Horimoto K, Hatta M, Loeber S, Halfmann PJ, Nakajima N, et al. Syrian hamsters as a small animal model for SARS-CoV-2 infection and countermeasure development. Proc Natl Acad Sci U S A. 2020;22:202009799. https://doi.org/10. 1073/pnas.2009799117.

13. Kreye J, Momsen Reincke S, Kornau H-C, Sanchez-Sendin E, Corman VM, Liu H, et al. A SARS-CoV-2 neutralizing antibody protects from lung pathology in COVID-19 hamster model. bioRxiv. 2020;2020.08.15.252320. https://doi.org/10.1101/2020. 08.15 .252320

14. Kaji T, Shimizu Y. Passive immunization against transmissible gastroenteritis virus in piglets by ingestion of milk of sows inoculated with attenuated virus. Natl Inst Anim Health Q (Tokyo). 1978;8(2):43-52.

15. Callow KA. Effect of specific humoral immunity and some nonspecific factors on resistance of volunteers to respiratory coronavirus infection. J Hyg (Camb). 1985;95(1):173-80.

16. Shan C, Yao Y-F, Yang X-L, Zhou Y-W, Gao G, Peng Y, et al. Infection with novel coronavirus (SARS-CoV-2) causes pneumonia in rhesus macaques. Cell Res. 2020;30:670-7. https://doi.org/10. 1038/s41422-020-0364-z.

17. Abou-Youssef MH, Ristic M. Protective effect of immunoglobulins in serum and milk of sows exposed to transmissible gastroenteritis virus. Can J Comp Med. 1975;39(1):41-5.

18. Morilla A, Klemm RC, Sprino P, Ristic M. Neutralization of a transmissible gastroenteritis virus of swine by colostral antibodies elicited by intestine and cell culture-propagated virus. Am J Vet Sci. 1976;37(9):1011-6.

19. Sprino PJ, Ristic M. Intestinal, pulmonary, and serum antibody responses of feeder pigs exposed to transmissible gastroenteritis virus by the oral and the oral-intranasal routes in inoculation. Am J Vet Res. 1982;43(2):255-61.

20. de Arriba ML, Carvajal A, Pozo J, Rubio P. Mucosal and systemic isotype-specific antibody responses and protection in conventional pigs exposed to virulent or attenuated porcine epidemic diarrhoea virus. Vet Immunol Immunopathol. 2002;85(1-2):85-97.

21. Heckert RA, Saif LJ, Mengel JP, Myers GW. Isotype-specific antibody responses to bovine coronavirus structural proteins in serum, feces, and mucosal secretions from experimentally challengeexposed colostrum-deprived calves. Am J Vet Res. 1991;52(5): 692-9.

22. Deng W, Bao L, Liu J, Xiao C, Liu J, Xue J, et al. Primary exposure to SARS-CoV-2 protects against reinfection in Rhesus macaques. Science. 2020; eabc5343. https://doi.org/10.1126/science.abc5343

23. Moxley RA, Olson LD, Solorzano RF. Relationship among transmissible gastroenteritis virus antibody titers in serum, colostrum, and milk from vaccinated sows, and protection in their suckling pigs. Am J Vet Res. 1989;50(1):119-25.

24. Ikemori Y, Ohta M, Umeda K, Icatlo FC Jr, Kuroki M, Yokoyama $\mathrm{H}$, et al. Passive protection of neonatal calves against bovine coronavirus-induced diarrhea by administration of egg yolk or colostrum antibody powder. Vet Microbiol. 1997;58(2-4):105-11.

25. Callow KA, Parry HF, Sergeant M, Tyrrell DA. The time course of the immune response to experimental coronavirus infection of man. Epidemiol Infect. 1990;105(2):435-46.
26. Muth D, Corman VM, Meyer B, Assiri A, Al-Masri M, Farah M, et al. Infectious Middle East Respiratory Syndrome coronavirus excretion and serotype variability based on live virus isolates from patients in Saudi Arabia. J Clin Microbiol. 2015;53(9):2951-5.

27. Corman VM, Albarrak AM, Senosi Omrani A, Albarrak MM, Farah ME, Almasri M, et al. Viral shedding and antibody response in 37 patients with Middle East Respiratory Syndrome coronavirus infection. Clin Infect Dis. 2016;62(4):477-83.

28. Okba NMA, Stalin Raj V, Widjaja I, GeurtsvanKessel CH, de Bruin E, Chandler FD, et al. Sensitive and specific detection of low-level antibody responses in mild Middle East Respiratory Syndrome coronavirus infections. Emerg Infect Dis. 2019;25(10): 1868-77.

29. Choe PG, Perera RAPM, Park WB, Song KH, Bang JH, Kim ES, et al. MERS-CoV antibody responses 1 year after symptom onset, South Korea, 2015. Emerg Infect Dis. 2017;23(7):1079-84.

30. Payne DC, Iblan I, Rha B, Alqasrawi S, Haddadin A, Al Nsour M, et al. Persistence of antibodies against Middle East Respiratory Syndrome coronavirus. Emerg Infect Dis. 2016;22(10):1824-6.

31. Liu L, To KK-W, Chan K-H, Wong Y-C, Zhou R, Kwan K-Y, et al. High neutralizing antibody titer in intensive care unit patients with COVID-19. Emerg Infect Dis. 2020;3:1-30. https://doi.org/10. 1080/22221751.2020.1791738.

32. Nielsen SCA, Yang F, Jackson KJL, Hoh RA, Röltgen K, Stevens $\mathrm{B}$, et al. Human B cell clonal expansion and convergent antibody responses to SARS-CoV-2. bioRxiv. 2020;2020.07.08.194456. https://doi.org/10.1101/2020.07.08.194456

33. Lv H, Wu NC, Tsang OT-Y, Yuan M, Perera RAPM, Leung WS, et al. Cross-reactive antibody response between SARS-CoV-2 and SARS-CoV infections. Cell Rep. 2020;18:107725. https://doi.org/ 10.1016/j.celrep.2020.107725.

34. Wu F, Liu M, Wang A, Lu L, Wang Q, Gu C, et al. Evaluating the association of clinical characteristics with neutralizing antibody levels in patients who have recovered from mild COVID-19 in Shanghai, China. JAMA Intern Med. 2020. https://doi.org/10. 1001/jamainternmed.2020.4616.

35. McAndrews KM, Dowlatshahi DP, Dai J, Becker LM, Hensel J, Snowden LM, et al. Heterogeneous antibodies against SARS-CoV2 spike receptor binding domain and nucleocapsid with implications on COVID-19 immunity. JCI Insight. 2020;14:142386. https://doi.org/10.1172/jci.insight.142386.

36. Iyer AS, Jones FK, Nodoushani A, Kelly M, Becker M, Slater D, et al. Dynamics and significance of the antibody response to SARSCoV-2 infection. medRxiv. 2020;2020.07.18.20155374. https:// doi.org/10.1101/2020.07.18.20155374

37. Juno JA, Tan H-X, Lee WS, Reynaldi A, Kelly HG, Wragg K, et al. Humoral and cellular and circulating follicular helper T cell responses in recovered patients with COVID-19. Nat Med. 2020;26:1428-34. https://doi.org/10.1038/s41591-020-0995-0.

38. Hu WT, Howell JC, Ozturk T, Benameur K, Bassit LC, Ramonell $\mathrm{R}$, et al. Antibody profiles according to mild or severe SARS-CoV2 infection, Atlanta, Georgia, USA, 2020. Emerg Infect Dis. 2020;28:26(12). https://doi.org/10.3201/eid2612.203334.

39. Wan J, Xing S, Ding L, Wang Y, Gu C, Wu Y, et al. Human-IgGneutralizing monoclonal antibodies block the SARS-CoV-2 infection. Cell Rep. 2020;3:107918. https://doi.org/10.1016/j.celrep. 2020.107918.

40. Suthar MS, Zimmerman M, Kauffman R, Mantus G, Linderman S, Vanderheiden A, et al. Rapid generation of neutralizing antibody responses in COVID-19 patients. Cell Rep Med. 2020;1(3):100040. https://doi.org/10.1016/j.xcrm.2020.100040.

41. Okba NMA, Müller MA, Li W, Wang C, GeurtsvanKessel CH, Corman VM, et al. Severe acute respiratory syndrome coronavirus 2-specific antibody responses in coronavirus disease patients. Emerg Infect Dis. 2020;26(7):1478-88. 
42. Varnaite R, Garcia M, Glans H, Maleki KT, Sandberg JT, Tynell J, et al. Expansion of SARS-CoV-2-specific antibody-secreting cells and generation of neutralizing antibodies in hospitalized COVID19 patients. J Immunol. 2020;ji2000717. https://doi.org/10.4049/ jimmunol.2000717

43. Weisberg SP, Connors T, Zhu Y, Baldwin M, Lin W-H, Wontakal $\mathrm{S}$, et al. Antibody response to SARS-CoV-2 are distinct in children with MIS-C compared to adults with COVID-19. medRxiv. 2020;2020.07.12.20151068. https://doi.org/10.1101/2020.07.12. 20151068

44. Yonker LM, Neilan AM, Bartsch Y, Patel AB, Regan J, Arya P, et al. Pediatric SARS-CoV-2: clinical presentation, infectivity, and immune responses. J Pediatr. 2020;S0022-3476(20)31023-4. https://doi.org/10.1016/j/jpeds.2020.08.037

45. Anderson EM, Diorio C, Goodwin EC, McNerney KO, Weirick $\mathrm{ME}$, Gouma S, et al. SARS-CoV-2 antibody responses in children with MIS-C and mild and severe COVID-19. medRxiv. 2020;2020.08.17.20176552. https://doi.org/10.1101/2020.08.17. 20176552

46. Dulipsingh L, Ibrahim D, Schaefer EJ, Crowell R, Diffenderfer MR, Williams K, et al. SARS-CoV-2 serology and virology trends in donors and recipients of convalescent plasma. Transfus Apher Sci. 2020;25:102922. https://doi.org/10.1016/j.transci.2020. 102922.

47. Young BE, Ong SWX, Ng LFP, Anderson DE, Chia WN, Chia PY, et al. Viral dynamics and immune correlates of COVID-19 disease severity. Clin Infect Dis. 2020; ciaa1280. https://doi.org/10.1093/ cid/ciaa1280

48. Carta M, Bragagnolo L, Tramarin A, Barzon E, Cappelletti A, Pascarella M, et al. Anti SARS-CoV-2 antibodies monitoring in a group of residents in a long term care facility during COVID-19 pandemic peak. Diagnosis. 2020. https://doi.org/10.1515/dx-20200094.

49. Takahashi T, Ellingson MK, Wong P, Israelow B, Lucas C, Klein J, et al. Sex differences in immune responses that underlie COVID-19 disease outcomes. Nature. 2020. https://doi.org/10.1038/s41586020-2700-3.

50. Berry JD, Jones S, Drebot MA, Andonov A, Sabara M, Yuan XY, et al. Development and characterization of neutralizing monoclonal antibody to the SARS-coronavirus. J Virol Methods. 2004;120(1): 87-96.

51. Reed SE. The behavior of recent isolates of human respiratory coronavirus in vitro and in volunteers: evidence of heterogeneity among 229E-related strains. J Med Virol. 1984;13(2):179-92.

52. Kim Y-S, Aigerim A, Park U, Kim Y, Rhee J-Y, Choi J-P, et al. Sequential emergence and wide spread of neutralization escape Middle East Respiratory Syndrome coronavirus mutants, South Korea, 2015. Emerg Infect Dis. 2019;25(6):1161-8.

53. Rani M, Bolles M, Donaldson EF, Van Blarcom T, Baric R, Iverson $\mathrm{B}$, et al. Increased antibody affinity confers broad in vitro protection against escape mutants of severe acute respiratory syndrome coronavirus. J Virol. 2012;86(17):9113-23.

54. To KK-W, Hung IF-N, Ip JD, Chu AW-H, Chan W-M, Tam AR, et al. COVID-19 re-infection by a phylogenetically distinct SARScoronavirus-2 strain confirmed by whole genome sequencing. Clin Infect Dis. 2020; ciaa1275. https://doi.org/10.1093/cid/ciaa1275.

55. Zhang F, Gan R, Zhen Z, Hu X, Li X, Zhou F, et al. Adaptive immune responses to SARS-CoV-2 infection in severe versus mild individuals. Signal Transduct Target Ther. 2020;5(1):156.

56. Rodda LB, Netland J, Shehata L, Pruner KB, Morawski PM, Thouvenel C, et al. Functional SARS-CoV-2-specific immune memory persists after mild COVID-19. medRxiv. 2020;2020.08.11.20171843. https://doi.org/10.1101/2020.08.11. 20171843

57. Braun J, Loyal L, Frentsch M, Wendisch D, Georg P, Kurth F, et al. SARS-CoV-2-reactive $\mathrm{T}$ cells in healthy donors and patients with
COVID-19. Nature. 2020. https://doi.org/10.1038/s41586-0202598-9.

58. Kaneko N, Kuo H-H, Boucau J, Farmer JR, Allard-Charnard H, Mahajan VS, et al. Loss of Bcl-6-expressing T follicular helper cells and germinal centers in COVID-19. Cell. 2020;S00928674(20)31067-9.

59. Cimolai N. Enzyme-linked immunoassay (conventional solid phase). Chapter 11. In: Cimolai N. Serodiagnosis of the infectious diseases: Mycoplasma pneumoniae. Kluwer Academic Publishers, Boston, pp 69-76 1999.

60. Cimolai N Serodiagnosis of bacterial infections. Chapter 4. In: Cimolai $\mathrm{N}$ - ed. Laboratory diagnosis of bacterial infections. Marcel Dekker, Inc., New York, pp. 55-82 2001.

61. Shook-Sa B, Boyce RM, Aiello AE. Estimation without representation: early severe acute respiratory syndrome coronavirus 2 seroprevalence studies and the path forward. J Infect Dis. 2020;jiaa429. https://doi.org/10.1093/infdis/jiaa429

62. Sempos CT, Tian L. Adjusting coronavirus prevalence estimates for laboratory test kit error. Am J Epidemiol. 2020;kwaa174. https://doi.org/10.1093/aje/kwaa174

63. Deeks JJ, Dinnes J, Takwoingi Y, Davenport C, Spijker R, TaylorPhillips S, et al. Antibody tests for identification of current and pat infection with SARS-CoV-2. Cochrane Database Syst Rev. 2020;6(6):CD013652.

64. Chia WK, Spence L, Dunkley L, Bradbury W. Development of urease conjugated enzyme-linked immunosorbent assay (ELISA) for the detection of IgM and IgG antibodies for the detection against Mycoplasma pneumoniae in human sera. Diagn Microbiol Infect Dis. 1988;11(2):101-7.

65. Charlton CL, Kanji JN, Johal K, Bailey A, Plitt SS, MacDonald C, et al. Evaluation of six commercial mid to high volume antibody and six point of care lateral flow assays for detection of SARSCoV-2 antibodies. J Clin Microbiol. 2020;JCM.01361-20. https:// doi.org/10.1128/JCM.01361-20

66. Van Elslande J, Decru B, Jonckheere S, Van Wijngaerden E, Houben E, Vandecandelaere P, et al. Antibody response against SARS-CoV-2 spike protein and nucleoprotein evaluated by 4 automated immunoassays and 2 ELISAs. Clin Microbiol Infect. 2020;S1198-743X(20)30446-8. https://doi.org/10.1016/j.cmi. 2020.07.038

67. Bryan A, Pepper G, Wener MH, Fink SL, Morishima C, Chaudhary A, et al. Performance characteristics of the Abbott Architect SARSCoV-2 IgG assay and seroprevalence in Boise, Idaho. J Clin Microbiol. 2020;58(8):e00941-20.

68. Theel ES, Jarring J, Hilgart H, Granger D. Performance characteristics of four high-throughput immunoassays for detection of IgG antibodies against SARS-CoV-2. J Clin Microbiol. 2020;58(8): e01243-20.

69. Brochot E, Demey B, Handala L, François C, Duverlie G, Castelain S. Comparison of different serological assays for SARS-CoV-2 in real life. J Clin Virol. 2020;130:104569. https://doi.org/10.1016/j. jcv.2020.104569.

70. Whitman JD, Hiatt J, Mowery CT, Shy BR, Yu R, Yamamoto TN, et al. Evaluation of SARS-CoV-2 serology assays reveals a range of test performance. Nat Biotechnol. 2020. https://doi.org/10.1038/ s41587-020-0659-0.

71. Herroelen PH, Martens GA, De Smet D, Swaerts K, Decavele A-S. Humoral immune response to SARS-CoV-2. Am J Clin Pathol. 2020;aqaa140. https://doi.org/10.1093/ajcp/aqaa140

72. Liu W, Liu L, Kou G, Zheng Y, Ding Y, Ni W, et al. Evaluation of nucleocapsid and spike protein-based enzyme-linked immunosorbent assays for detecting antibodies against SARS-CoV-2. J Clin Microbiol. 2020;58(6):e00461-20.

73. Roy V, Fischinger S, Atyeo C, Siein M, Loos C, Balazs A, et al. SARS-CoV-2-specific ELISA development. J Immunol Methods. 2020 Aug;8:112832. https://doi.org/10.1016/j.jim.2020.112832. 
74. Peterhoff D, Glück V, Vogel M, Schuster P, Schütz A, Neubert P, et al. A highly specific and sensitive serological assay detects SARS-CoV-2 antibody levels in COVID-19 patients that correlate with neutralization. Infection. 2020. https://doi.org/10.1007/s. 15010-020-01503-7.

75. Walker SN, Chokkalingam N, Reuschel EL, Purwar M, Xu Z, Gary EN, et al. SARS-CoV-2 assays to detect functional antibody responses that block ACE2 recognition in vaccinated animals and infected patients. J Clin Microbiol. 2020;JCM.01533-20. https:// doi.org/10.1128/JCM.01533-20

76. Fukushi S. Competitive ELISA for the detection of serum antibodies specific for Middle East Respiratory Syndrome coronavirus (MRES-CoV). Methods Mol Biol. 2020;2203:55-65.

77. Gniffke EP, Harrington WE, Dambrauskas N, Jiang Y, Trakhimets $\mathrm{O}$, Vigdorovich V, et al. Plasma from recovered COVID-19 subjects inhibits spike protein binding to ACE2 in a microsphere-based inhibition assay. J Infect Dis. 2020;jiaa508. https://doi.org/10.1093/ infdis/jiaa508

78. Hirotsu Y, Maejima M, Shibusawa M, Nagakubo Y, Hosaka K, Amemiya K, et al. Comparison of automated SARS-CoV-2 antigen test for COVID-19 infection with quantitative RT-PCR using 313 nasopharyngeal swabs including from 7 serially followed patients. Int J Infect Dis. 2020;S1201-9712(20)30658-5. https://doi.org/10. 1016/j.ijid.2020.08.029

79. Scohy A, Anantharajah A, Bodéus M, Kabamba-Mukadi B, Verroken A, Rodriguez-Villalobos H. Low performance of rapid antigen detection test as frontline testing for COVID-19 diagnosis. J Clin Virol. 2020;129:104455. https://doi.org/10.1016/j.jcv.2020. 104455.

80. Ogawa T, Fukumori T, Nishihara Y, Sekine T, Okuda N, Nishimura T, et al. Another false-positive problem for a SARSCoV-2 antigen test in Japan. J Clin Virol. 2020;25:104612. https://doi.org/10.1016/j/jev.2020.104612.

81. Guan M, Chen HY, Tang PH, Shen S, Goh P-Y, Tan Y-J, et al. Use of viral lysate antigen combined with recombinant protein in Western immunoblot assay as confirmatory test for serodiagnosis of severe acute respiratory syndrome. Clin Diagn Lab Immunol. 2004;11(6):1148-53.

82. Olvera A, Noguera-Julian M, Kilpelainen A, Romero-Martin L, Prado JG, Brander C. SARS-CoV-2 consensus-sequence and matching overlapping peptides design for COVID-19 immune studies and vaccine development. Vaccines. 2020;6:E444. https:// doi.org/10.3390/vaccines8030444.

83. van Tol S, Mögling R, Li W, Godeke G-J, Swart A, Bergmans B, et al. Accurate serology for SARS-CoV-2 and common human coronaviruses using a multiplex approach. Emerg Microbes Infect. 2020;20:1-24. https://doi.org/10.1080/22221751.2020. 1813636.
84. Crawford KHD, Eguia R, Dingens AS, Loes AN, Malone KD, Wolf CR, et al. Protocol and reagents for pseudotyping lentiviral particles with SARS-CoV-2 spike protein for neutralization assays. Viruses. 2020;12(5):513.

85. Hu J, Gao Q, He C, Huang A, Tang N, Wang K. Development of cell-based pseudovirus entry assay to identify potential viral entry inhibitors and neutralizing antibodies against SARS-CoV-2. Genes Dis. 2020. https://doi.org/10.1016/j.gendss.2020.07.006.

86. Abe K, Li Z, Samson R, Samavarchi-Tehrani P, Valcourt EJ, Wood $\mathrm{H}$, et al. A simple protein-based surrogate neutralization assay for SARS-CoV-2. JCI Insight. 2020;1:142362. https://doi.org/10. 1172/jci.insight. 142362.

87. Case JB, Rothlauf PW, Chen RE, Liu Z, Zhao H, Kim AS, et al. Neutralizing antibody and soluble ACE2 inhibition of a replicationcompetent VSV-SARS-CoV-2 and a clinical isolate of SARSCoV-2. Cell Host Microbe. 2020;S1931-3128(20)30362-0. https://doi.org/10.1016/j.chom.2020.06.021

88. Wang K, Long Q-X, Deng H-J, Hu J, Gao Q-Z, Zhang G-J, et al. Longitudinal dynamics of the neutralizing antibody response to SARS-CoV-2 infection. Clin Infect Dis. 2020; ciaa1143. https:// doi.org/10.1093/cid/ciaa1143

89. Han DP, Kim HG, Kim YB, Poon LLM, Cho MW. Development of a safe neutralization assay for SARS-CoV and characterization of S-glycoprotein. Virology. 2004;326(1):140-9.

90. Gousseff M, Penot P, Gallay L, Batisse D, Benech N, Bouiller K, et al. Clinical recurrences of COVID-19 symptoms after recovery: viral relapse, reinfection or inflammatory rebound? J Infect. 2020;S1063-4453(20)30454-0. https://doi.org/10.1016/j.jinf. 2020.06.073

91. Bentivegna E, Sentimentale A, Luciani M, Speranza ML, Guerritore L, Martelletti P. New IgM seroconversion and positive RT-PCR test after exposure to the virus in recovered COVID-19 patient. J Med Virol. 2020. https://doi.org/10.1002/jmv.26160, https://doi.org/10.1002/jmv.26160.

92. Tomassini S, Kotecha D, Bird PW, Folwell A, Biju S, Tang JW. Setting the criteria for SARS-CoV-2 reinfection-six possible cases. J Infect. 2020;S0163-4453(20)30546-6. https://doi.org/10.1016/j. jinf.2020.08.011

93. Van Elslande J, Vermeersch P, Vandervoort K, Wawina-Bokalanga T, Vanmechelen B, Wollants E, et al. Symptomatic SARS-CoV-2 reinfection by a phylogenetically distinct strain. Clin Infect Dis. 2020; ciaa1330. https://doi.org/10.1093/cid/ciaa1330

Publisher's Note Springer Nature remains neutral with regard to jurisdictional claims in published maps and institutional affiliations. 